\title{
PENTINGNYA PEMANFAATAN SISTEM INFORMASI MANAJEMEN DALAM MENINGKATKAN SISTEM PENJAMINAN MUTU PENDIDIKAN
}

Oleh:

\author{
ANI WAHYUNI, 17002114 \\ Sistem Informasi Manajemen-Jurusan Administrasi Pendidikan \\ Fakultas Ilmu Pendidikan, Universitas Negeri Padang \\ E-mail : aniwahyuni151@gmail.com
}

\begin{abstract}
ABSTRAK
Artikel ini bertujuan untuk mengambarkan dan mendeskripsikan mengenai (1)Pengertian SIM, Tujuan SIM, Manfaat SIM, (2) Implementasi SIM dalam manajemen sekolah serta (3)Mengetahui seberapa pentingnya pemanfaatan Sistem informasi Manajemen (SIM) dalam Meningkatkan Sistem Penjaminan Mutu Pendidikan. Dalam lembaga pendidikan manajemen harus dijalankan dengan baik untuk menjaga keberlangsunagn hidup pada lembaga pendidikan tersebut. Salah satu komponen yang dapat mengembangkan sebuah lembaga pendidikan tersebut adalah dengan adanya pengelolaan sistem informasi yang baik. Mekanisme manajemen yang kurang baik akan sangat berpengaruh terhadap mutu atau output pendidikan. Oleh karena itu, dengan melaksanakan manajemen tersebut secara professional diharapkan dapat meningkatkan mutu pendidikan. Dan dengan adanya pemanfaatan Sistem Informasi Manajemen tersebut dapat meningkatnya kualitas pendidikan.
\end{abstract}

Kata Kunci: Sistem Informasi Manajemen, Pemanfaatan SIM, Mutu Pendidikan

\section{PENDAHULUAN}

Seiring dengan perkembangan ilmu pengetahuan, teknologi informasi dan komunikasi menjadikan kemajuan ilmu pengetahuan di berbagai bidang seperti perusahaan atau organisasi, tanpa terkecuali di dalam bidang pendidikan. Keberadaan dan peran teknologi informasi tersebut telah membawa era baru dalam perkembangan pendidikan seperti saat sekarang ini. Pendidikan di era globalisasi seperti saat ini ditandai dengan perkembangan teknologi 
informasi dan komunikasi menuntut adanya penyempurnaan sistem pendidikan.

Pengembngan Sistem Informasi Manajemen pada lembaga pendidikan sangat dibutuhkan, karena dalam menghadapi persaingan global lembaga pendidikan dituntut untuk memberikan informasi lebih cepat,akurat dan nyaman yang merupakan bagian dari kualitas pelayanan, sehingga akan menjadi sebuah kenggulan persaingan (competitive adventage) (Rochaety, 2006).

Dengan pemanfaatan ilmu pengetahuan, dan teknologi, yang semakin berkembang dapat meningkatkan kualitas pembelajaran (Agustiandra \& Sabandi, 2019).

Manajemen di suatu lembaga pendidikan harus dijalankan dengan baik demi menjaga keberlangsunngan hidup pada lembaga pendidikan tersebut. Adapun salah satu komponen yang dapat mengembangkan sebuh lembaga pendidikan tersebut adalah dengan adanya pengelolaan Sistem Informasi Manajemen yang baik. Namun, masih banyak ditemui para pengelolaan pendidikan yang belum memanfaatkan Sistem Informasi Manajemen (SIM) tersebut yang akhirnya berdampak pada kurang optimalnya lembaga pendidikan dalam menjalankan fungsi-fungsi manajemen diantaranya: menyusun planning, organizing, actuating dan controlling. Sehingga dengan pengelolaan yang tidak dilandasi dengan ilmu manajemen tersebut akan mempengaruhi proses dan hasil yang tidak efektif dan efisien, maka diperlukanlah pemanfaatan Sistem Informasi Manajemen (SIM) yang terintegrasi dengan lembaga pendidikan yang dapat meningkatkan sistem penjaminan mutu pendidikan.

\section{PEMBAHASAN}

\section{A. Ringkasan Artikel}

\section{Pengertian SIM}

Menurut (Agustiandra \& Sabandi, 2019) Moeljodiharrjo dalam Sutabri (2005) Sistem Informasi Manajemen (SIM) adalah suatu metode untuk menghasilkan informasi yang tepat waktu bagi manajemen tentang lingkungan luar organisasi, dengan tujuan untuk menunjang proses pengambilan keputusan serta memperbaiki proses perencanaan dan pengawasan.

Menurut (Davis, 2002) mengatakan bahwa Sistem Informasi Manajemen adalah sebuah sistem manusia mesin yang terpadu (integrated), untuk menyajikan informasi guna mendukung fungsi operasi, manajemen, dan pengambilan keputusan dalam sebuah organisasi. 
Jadi, dapat kita simpulkan bahwa Sistem Informasi Manajemen (SIM) adalah suatu sistem yang dirancang untuk menyediakan data atau informasi guna mendukung untuk pengambilan keputusan pada kegiatan manajemen dalam suatu organisasi.

\section{Tujuan SIM}

Menurut (Lukman Ahmad, 2018) tujuan dibentuknya Sistem Informasi Manaejemn adalah supaya organisasi memiliki informasi yang bermanfaat dalam pembuatan keputusan manajemen, baik yang menyangkut keputusan-keputusan rutin maupun keputusan-keputusan yang strategis.

Adapun tujuan dari Sistem Informasi Manajemen (SIM) secara umum adalah sebagai berikut:

1) Agar organisasi dapat beroperasi secara efektif dan efisien, dengan adanya SIM dapat mengerjakan pekerjaan rutin secara cepat dan mudah. Efektifitas merupakan target dari sistem pendukung informasi sedangkan efesiensi dicapai berkat prestasi sistem pengelolaan transaksi.

2) Agar organisasi dapat memberikan pelayanan/service yang lebih baik,SIM dapat memberikan kemudahan dalam memberi informasi

3) Untuk pengumpulan data dan menyediakan suatu informasi guna mendukung untuk pengambilan keputusan.

4) Menyediakan suatu informasi yang dipergunakan di dalam suatu perencanaan, pengemdalian, pengevaluasiaan, dan juga perbaikan berkelanjutan di dalam organisasi

5) Menyediakan suatu informasi yang dipergunakan di dalam suatu perhitungan harga pokok produk, jasa dan tujuan lainnya yang diinginkan oleh manajemen.

\section{Manfaat SIM}

Sistem Informasi Manajemen (SIM) meliliki banyak manfaat bagi penggunaanya. Ada beberapa manfaat sistem informasi manajemen antara lain sebagai berikut:

1) Dapat meningkatkan aksebilitas data yang disajikan secara akurat dan tepat waktu bagi para pemakainya. Tanpa mngharuskan adanya perntara sistem informasi.

2) Dapat Memudahkan pihak manajemen untuk melakukan pengawasan, pengarahan dan pndelegasian kerja 
3) Dapat Meningkatkan kualitas sumber daya manausia

4) Dapat Meningkatkan produktivitas bagi perusahaan

5) Dapat Menjamin tersedianya kualitas dan keterampilan dalam memanfaatkan sistem informasi secara kritis.

6) Dapat Mengidentifikasi kebutuhankebutuhan akan terampilan pendukung sistem informasi.

7) Dapat Mengembangkan proses perencanaan yang efektif.

\section{Implementasi SIM dalam Manajemen}

\section{Sekolah}

Sistem informasi manajemen sekolah dapat membantu manajer dalam menentukan tujuan sekolah, membuat rencana jangka panjang, menentukan kinerja guru, dan keberhasilan sekolah. Sehingga dengan implementasi SIM dalam manajemen sekolah dapat digunakan sebagai alat untuk menumbuhkan dan menggunakan kepemimpinan pendidikan bagi para manajer yang ada di sekolah tersebut.

Adapun Implementasi SIM dalam Manajemen Sekolah menurut (Lestari, 2017) adalah seperti:
1) Koneksi dan Setting yang terdiri dari : identitas sekolah, setting tahun ajaran, setting kurikulum, koneksi database, dan format tanggal.

2) Pengelolaan Peserta Didik seperti: pengelolaan biodata masing-masing peserta didik, beasiswa, kasus kedisiplinan, data kesehatan, data periksa, prestasi, perpindahan (mutasi) peserta didik, sampai pengelolaan data alumni.

3) Pengelolaan Akademik meliputi: laporan nilai hasil ujian secara priodik, data absensi, data bimbingan dan penyuluhan, data kasus peserta didik, rencana pengajaran, pengelolaan mata pelajaran, penjadwalan, dan prestasi akademik.

4) Pengelolaan Guru dan Karyawan meliputi: manajemen biodata guru dan karyawan, data keluarga, riwayat pendidikan, pendidikan tambahan (kursus, training, seminar, workshop dsb)

5) Pengelolan Keuangan, meliputi: manajemen pembayaran biaya pendidikan, administrasi dana BOS (Bantuan Operasional Sekolah) dan penggunaanya, dana bantuan dari Pemkab berupa dana DPA) Dokumen pelaksanaan Anggaran), 
dana dari orang tua peserta didik dan dana bantuan yang lainnya.

6) Pengelolaan Perpustakaan, meliputi: pengelolaan buku (judul, kategori\&deskripsi), status keanggotaan dan pemimjam, stock inventory, jurnal keluar masuk buku, laporan-laporan terdiri dari: statistic pemimjaman, dan rekap pengembalian.

7) Pelaporan, meliputi: pelaporan peserta didik (nomor induk peserta didik, kesehatan, periksa kesehatan, beasiswa, kasus dan bimbingan) per peserta didik, per kelas dan seluruh peserta didik, pelaporan guru/pegawai (induk pegawai, bidang (pengajaran), rencana pengajaran, nilai kelulusan, statistic dan laporan ke DEPDIKBUD (data sekolah, peserta didik dan guru).

\section{Pentingnya Pemanfaatan Sistem Informasi Manajemen (SIM) dalam Meningkatkan Sistem Penjaminan Mutu Pendidikan}

Pentingnya pemanfaatan sistem informasi manajemen dalam pembelajaran diperlukan karena untuk memaksimalkan pencapaian tujuan pebelajaran dan dalam meningkatkan sistem penjaminan mutu pendidikan.

Pemanfaatan SIM dalam meningkatkan sistem penjaminan mutu pendidikan diantaranya adalah:

a) Pemanfaatan SIM dalam Perencanaan Pembelajaran

Pemanfatan SIM dalam perencanaan pembelajaran adalah Meliputi: website sekolah, e-learning, menyusun rencana pembelajaran setiap semester tahun akademik, yang tahap akhirnya dalam bentuk softcopy dan hardcopy.

b) Pemanfaatan SIM dalam Pelaksanaan Pembelajaran Pemanfaatan SIM dalam pelaksanaan pembelajaran yaitu elearning adalah misalnya guru ada kegiatan lain yang menyebabkan dia tidak dapat hadir dalam tatap muka dikelas. Namun tidak berarti bahwa pembelajarn terhenti dalam kondisi tersebut. Maka dengan adanya sistem informasi e-learning guru dapat memberi tugas kepada siswa. Dengan cara guru mengupload materi tersebut ke e-learning dan kemudian siswa dapat mendownload materi tersebut. Maka komunikasi 
guru tetap berjalan walaupun tidak secara langsung. Siswa dapat mengkomunikasikan kesulitan yang dihadapinya, dan sebaliknya guru bisa mengnanggapi melalui sistem informasi -learning ini.

c) Pemanfaatan SIM dalam Pengawasan Pembelajaran

Pemanfaatan SIM dalam pengawasan pembelajaran yaitu elearning adalah dalam pemautauan proses kegiatan belajar mengajar waka akademik bisa melihat data seperti data hasil nilai, soal ujian dll.

d) Pemanfaatan SIM dalam Evaluasi Pembelajaran

\begin{tabular}{lll}
\multicolumn{2}{c}{ Pemanfaatan SIM } & dalam \\
evaluasi pembelajaran & adalah \\
pelaksanaan ujian secara & online, \\
seperti UTS, UAS, UN dll. &
\end{tabular}

Secara kelembagaan, Sistem Penjaminan Mutu Pendidikan diposisikan sebagai bagian dari keseluruhan fungsi manajemen pendidikan. Sistem Penjaminan Mutu Pendidikan sebagai salah satu fungsi manajemen pendidikan mengemban tugas dan tanggung jawab dalam mengukur dan menilai pemenuhan standar mutu sebagaimana yang telah ditetapkan dalam kebijakan atau regulasi. Sistem penjaminan mutu pendidikan dalam kegiatannya focu terhadap peningkatan mutu secara brkelanjutan dengan cara mengukur dan menilai mutu sistem pendidikan, kinerja industry pendidikan, dan mutu program studi (Fattah, 2012).

Dengan diterapkan SIM disekolah dapat meningkatkan mutu pendidikan, dimana para guru dapat memanfaat Sistem Informasi Manajemen (SIM) dalam proses pembelajaran yaitu guru berusaha memberikan informasi berupa materi bahan ajar kepada siswa tepat waktu dengan memanfaatkan sistem informasi e-learning, penggunaaan jaringan internet untuk sumber belajar sehingga dengan memanfaat SIM pada lembaga pendidikan dapat membantu guru dan siswa dalam proses pembelajaran yang akhirnya akan meningkatkan kualitas dan mutu pendidikan.

Menurut (Ramadanti \& Sabandi, 2019) Dengan pemanfaatan teknologi Sistem Informasi Manajemen (SIM) akan dapat mengurangi tahap proses kerja dalam organisasi. Pemanfaatan dari perkembangan teknologi informasi inilah yang dapat membantu setiap pekerjaan yang dilakukan dalam sebuah organisasi. 


\section{B. Kajian Analitis}

Berdasarkan kajian teori dari ringkasan artikel diatas maka dapat kita simpulkan bahwa pengertian SIM adalah suatu sistem yang dirancang untuk menyediakan data atau informasi yang akurat, cermat, tepat waktu yang digunakan dalam pengambilan suatu keputusan pada kegiatan manajemen di dalam suatu organisasi, sehingga memungkinkan mereka merencanakan dan mengendalikan manajemen untuk mengoptimalkan pertumbuhan di dalam organisasi tersebut.

Dan dalam rangka menunjang agar tercapainya sasaran dan tujuan operasional fungsi-fungsi manajemen dalam suatu organisasi pendidikan. Maka dengan adanya sistem informasi manajemen pada lembaga pendidikan akan merasakan beberapa manfaat diantaranya:

a) Dengan adanya SIM pada lembaga pendidikan maka tersedianya suatu data dan informasi pada lembaga pendidikan

b) Dengan adanya SIM pada lmbaga pendidikan maka terintegrasinya data dan informasi pendidikan untuk mendukung dalam proses pengambilan keputusan c) Dan dengan adanya SIM pada lembaga pendidikan maka tersedianya data dan informasi yang lengkap bagi seluruh stakeholders yang berkepentingan pada bidang pendidikan tersebut.

Jadi untuk dapat meningkatkan sistem penjaminan mutu pendidikan maka diperlukanlah pemanfaatan SIM dimana terbuktinya peran sistem informasi manajemen pendidikaan sesuai dengan strategi apa yang direncanakan. Dimana hal itu dapat dilihat dari meningkatnya jumlah input oleh setiap tahunnya, prestasi siswa yang selalu bertambah, dan berkembang dalam bidang akademik maupun non akademik kebijakan kepala sekolah, peran guru dan masyarakat serta stakeholders. Dengan Sistem Informasi Manajemen yang terus berkembang di lembaga pendidikan dapat bekerja secara cepat dan akurat sehingga produktivitas kerja di lembaga pendidikan lebih meningkat dan berdampak pada meningkatnya mutu pendidikan.

\section{PENUTUP}

\section{A. Kesimpulan}

Berdasarkan hasil pembahasan diatas maka dapat kita simpulkan bahwa pemanfaatan SIM sangat penting dalam 
meningkatkan sistem penjaminan mutu pendidikan diantaranya adalah dalam impelemntasi SIM dalam manajemen sekolah yaitu (1) Koneksi dan Setting: identitas sekolah, setting tahun ajar. (2) Pengelolaan Peserta Didik, (3) Pengelolaan Akademik, (4) Pengelolaan Guru dan Karyawan, (5) Pengelolaan Keuangan, (6) Pengelolaaan Perpustakaan, dan (7) Pelaporan. Sedangkan pemanfaatan SIM dalam meningkatkan sistem penjaminan mutu pendidikan adalah dalam (a) Perencanaan Pembelajaran meliputi: menyususun rencanan pembelajaran,website sekolah dll, (b) Pelaksanaan Pembelajaran seperti dalam menggunakan sistem informasi e-learning dalam proses pembelajaran, (c) Pengawasan Pembelajaran, seperti pemantauan dalam kegiatan pembelajaran seperti, hasil data nilai siswa, soal ujian, dll serta (d) Evaluasi Pembelajaran seperti pelaksaan ujian secara online menggunakan sistem informasi manajemen.

Jadi dengan diterapkannya SIM dalam dunia pendidikan maka data atau informasi yang tersimpan dan terolah secara cepat,akurat, tepat ,nyaman, tepat guna, tepat sasaran, fleksibel, dapat dipercaya jelas, dan tidak memberikan tafsiran yang berbeda dalam memanfaatkan informasi bagi penggunanya. Sehingga dapat meningkatnya sistem penjaminan mutu pendidikan

\section{B. Saran}

Diharapkan bagi sekolah, seorang kepala sekolah dan guru dan dengan adanya dukungan dari pengawas harus dapat memegang tanggung jawab atas sistem informasi manajemen yang telah dilaksanakan agar terus dapat meningkatkan penjaminan mutu pendidikan, dan disarankan agar dalam pelaksanaan sistem informasi manajemen agar lebih dikembangkan lagi.

\section{REFERENSI}

Agustiandra, V., \& Sabandi, A. (2019). Persepsi Guru Terhadap Penerapan Sistem Informasi Manajemen Akademik Di Sekolah Menengah Kejuruan (Smk) Negeri 3 Padang. Jurnal Bahana Manajemen Pendidikan, 8(I), 1-8. Retrieved from http://ejournal.unp.ac.id/index.php/baha na/article/view/103704

Davis, G. (2002). Kerangka Dasar Sistem Informasi Manajemen Bagian I Pengantar. Jakarta: Pustaka Binaman Presindo. 
Fattah, N. (2012). Sistem Penjaminan Mutu Pendidikan. Bandung: PT.Remaja Rosdakarya.

Lestari, P. (2017). Implementasi Sistem Informasi Manajemen Sekolah dalam Meningkatkan Mutu Layanan Pendidikan. Jurnal Ilmiah Mahasiswa, 5(1), 61-68.

Lukman Ahmad, M. (2018). Sistem Informasi Manajemen. Banda Aceh: Lembaga Komunitas Teknologi Aceh (KITA).

Ramadanti, G. B., \& Sabandi, A. (2019).

Persepsi Pegawai Terhadap Penerapan Sistem Informasi Manajemen Kepegawaian (SIMPEG) di Badan Kepegawaian Daerah Provinsi Sumatera Barat. Jurnal Bahana Manajemen Pendidikan, 8(3), 187-194. https://doi.org/10.11693/hyhz20181000 233

Rochaety, E. (2006). Sistem Informasi Manajemen Pendidikan. Jakarta: Bumi Aksara. 